\title{
Persepsi Masyarakat Aceh Barat Terhadap Rencana Pemekaran Kota Meulaboh Sebagai Daerah Otonomi Baru
}

\author{
Fadhil Ilhamsyah ${ }^{1}$, Zuhrizal Fadhly ${ }^{2}$ \\ ${ }^{1}$ Jurusan Ilmu Administrasi Negara Universitas Teuku Umar, Indonesia \\ ${ }_{2}^{2}$ Jurusan Ilmu Administrasi Negara Universitas Teuku Umar, Indonesia
}

\begin{tabular}{l} 
ARTICLE INFORMATION \\
\hline Received: October 15, 2020 \\
Revised: November 01, 2020 \\
Accepted: November 10, 2020 \\
Available online: November 14, 2020 \\
KEYWORDS \\
\hline perception, society, expansion, new autonomous \\
regions \\
CORRESPONDENCE \\
\hline Phone: +6285360916056 \\
E-mail: fadhil.ilhamsyah@utu.ac.id \\
\hline
\end{tabular}

\author{
A B S T R A C T
}

\section{PENDAHULUAN}

Desentralisasi merupakan cara untuk mencapai salah satu tujuan Negara yaitu dalam penyelenggaraan pelayanan publik, Desentralisasi diharapkan mendekatkan pelayananan masayarakat dan menyelesaikan masalah yang beragam dari setiap daerah . Desentralisasi sering disebut pemberian otonomi kepada daerah untuk meyelenggarakan pemerintahan sendiri dengan tujuan untuk memperbaiki pelayan publik dan mengurangi kemiskinan (Alcock, 1997; Huda, 2014; Ikhsan, 2015). Pembentukan daerah otonomi, diantaranya melalui pemekaran daerah juga merupakan salah satu upaya untuk memperbaiki pelayanan publik dan mempercepat pembangunan daerah. Selama 16 tahun era desentralisasi, laju pertambahan DOB amat cepat. Selain pertumbuhan DOB, transfer penerimaan pusat ke daerah juga mengalami peningkatan (Ikhsan et al., 2020; Ikhsan, 2016; Trikurniasih et al., 2019).

Dengan bergulirnya otonomi daerah, setiap daerah di Indonesia berlomba-lomba untuk melakukan pemekaran daerah. Pemekaran tidak hanya terjadi pada tingkat provinsi tetapi terjadi juga ditingkat kabupaten/kota bahkan kecamatan. Fenomena pemekaran dapat diibaratkan seperti "jamur" yang tumbuh subur di mana-mana (Beli, 2016; Ikhsan, 2016; Yani, 2016). Berlomba-lomba daerah untuk memekarkan wilayahnya dikarenakan secara aturan hukum ada Undangundang yang telah memberikan ruang untuk melakukan pemekaran tersebut (Kombuno, 2017; Trikurniasih et al., 2019). Dikarenakan hal, pertumbuhan daerah yang dimekarkan menjadi sangat pesat. Terhitung sejak tahun 1999-2004 daerah yang dimekarkan mencapai 7 Provinsi, 115 Kabupaten dan 26 Kota, sementara dari tahun 2005-2014 terdapat 1 Provinsi, 66 Kabupaten dan 8 Kota. Saat ini berdasarkan catatan Kemendagri tahun 2014 total daerah otonom di Indonesia mencapai 542 daerah otonom yang terdiri 34 Provinsi, 415 Kabupaten dan 93 Kota (Bauw, 2018).

Semangat pemekaran daerah juga diikuti oleh sejumlah tokoh di Kabupaten Aceh Barat untuk memekarkan Kota Meulaboh. Pada tahun 2015, ada sejumlah tokoh masyarakat Aceh Barat membentuk tim panitia pemekaran Kotamadya Meulaboh. Upaya pemekaran ini didasari atas keinginan menjadikan Kota Meulaboh sebagai kawasan industri dan kawasan perekonomian. Menurut (Ikhsan, 2016), Pemekaran Kota Meulaboh harus ditetapkan sebagi hal yang mendesak, mengingat Kota Meulaboh merupakan kota yang sudah lama berdiri di wilayah barat selatan Aceh namun hingga saat ini belum dapat berkembang secara optimal. Padahal Kota Meulaboh merupakan kota niaga dimana arus perekonomian kota ini sangat tinggi. Pelayanan yang diberikan kepada masyarakat di bidang pendidikan, kesehatan dan sebagainya belum optimal, mengingat Kabupaten Aceh Barat memiliki wilayah geografis sebanyak 12 kecamatan sehingga tidak memiliki focus yang jelas dalam pembangunan. Dengan adanya pembentukan Kota Madya Meulaboh diharapkan akan tercipta lapangan kerja baru dan iklim investasi yang membaik sehingga membuka peluang usaha.

Rencana pemekaran Kota Meulaboh ini mendapat dukungan dari Pemerintah dan Dewan Perwakilan Rakyat Kabupaten Aceh Barat saat itu. Dukungan tersebut terlihat 
dari keseriusan Bupati Aceh Barat yang gencar melakukan lobilobi politik baik dengan elemen masyarakat di Aceh Barat, Gubernur Aceh, Dewan Perwakilan Rakyat Aceh, bahkan Dewan Perwakilan Daerah. Akhirnya, setelah mendapatkan rekomendasi dari Gubernur Aceh serta Dewan Perwakilan Rakyat Aceh, pada tanggal 15 Mei 2017 dokumen pembentukan Daerah Otonomi Baru (DOB) Kota Meulaboh diserahkan kepada Kemendagri untuk dapat dibahas dan ditetapkan sebagai salah satu Daerah Otonomi Baru.

Upaya pemekaran Kota Meulaboh tidaklah berjalan mulus sebagaimana yang dicita-citakan. Disamping masih diterapkannya Moratorium Pemekaran Daerah oleh Pemerintah Pusat, upaya pemekaran mendapat penolakan oleh sebagian masyarakat termasuk Bupati Aceh Barat saat ini. Pemekaran Kota Meulaboh dipandang hanya dijadikan isu untuk meraup suara pemilih dalam Pilkada 2017 serta Pemilu 2019. Hal ini kemudian membuat pro kontra di kalangan masyarakat Kabupaten Aceh Barat, ada masyarakat yang mendukung dan ada juga yang menolak rencana pemekaran Kota Meulaboh.

Menurut Makaganza (2008), Bahkan, istilah pemekaran daerah digunakan sebagai upaya untuk memurnikan bahasa (eupieisme) yang mengawali proses "perpisahan" atau "pemecahan" daerah guna membentuk satuan administrasi lokal baru (Makagansa, 2008; Reiza Macella, 2020). Ditinjau dari filosofi kerukunan, kata pemisahan atau pemecahan memiliki arti negatif, sehingga istilah pemekaran daerah dianggap lebih pas untuk mencirikan fase pembentukan DOB pasca reformasi di Indonesia. Lebih lanjut Murniati (2017) menjelaskan Secara umum pemekaran wilayah adalah proses pemekaran wilayah menjadi lebih dari satu wilayah dengan tujuan untuk meningkatkan pelayanan dan mempercepat pertumbuhan (Murniati, 2017).

Pendapat di atas sejalan dengan penjelasan UU No. 23 Tahun 2014 tentang Pemerintah Daerah dan PP No. 78 Tahun 2007 tentang Tata Cara Pembentukan, Penghapusan dan Penggabungan Daerah. Ditegaskan dalam peraturan perundang-undangan ini bahwa pemekaran daerah dapat berupa penggabungan beberapa daerah atau ruas-ruas wilayah yang berbatasan atau pemekaran dari satu daerah menjadi lebih dari satu daerah (Bauw, 2018; Kombuno, 2017). Sementara itu, secara substansi tujuan pemekaran daerah adalah untuk memperkuat pelayanan pemerintahan kepada masyarakat dalam arti mempercepat pertumbuhan ekonomi daerah, meningkatkan keamanan dan mewujudkan keseimbangan antara pembangunan pusat dengan daerah(Muqoyyidin, 2013; Ramdhani, 2019). Dengan demikian dapat disimpulkan bahwa pemekaran daerah ialah pemisahan satu daerah menjadi beberapa daerah atau penggabungan beberapa daerah menjadi satu daerah otonom yang bertujuan untuk meningkatkan pelayanan dan kesejahteraan masyarakat di suatu daerah.

Murniati (2017) juga menjelaskan bahwa ada beberapa alasan mengapa pemekaran daerah saat ini menjadi salah satu pendekatan yang paling banyak digunakan dalam penyelenggaraan pemerintahan daerah dan pembangunan pelayanan publik, yaitu:

1. Alasan membawa pelayanan lebih dekat dengan masyarakat.

Hal ini sebagian besar disebabkan oleh keterbatasan geografis, infrastruktur dan sarana transportasi yang minim.
2. Alasan historis.

Pemekaran wilayah dilakukan untuk kepentingan sejarah yaitu bahwa wilayah hasil pemekaran mempunyai arti sejarah tertentu.

3. Alasan kultural atau budaya (etnis).

Pemekaran wilayah terjadi karena diartikan adanya kesenjangan budaya antara daerah yang bersangkutan dengan daerah induknya..

4. Alasan ekonomi.

Pertumbuhan wilayah di daerah diharapkan dapat meningkatkan pembangunan.

5. Alasan anggaran.

Perluasan daerah dilakukan untuk mendapatkan anggaran dari Pemerintah. Seperti diketahui, daerah pemekaran akan mendapat anggaran dari daerah induk selama 3 tahun dan mendapat dukungan dari pemerintah pusat (DAU dan DAK).

6. Alasan keadilan.

Pemekaran digunakan sebagai alasan untuk melakukan keadilan. Artinya, pemekaran daerah diharapkan mampu menciptakan keadilan bagi pemenuhan peran publik dan pemerataan pertumbuhan. (Murniati, 2017)

Di satu sisi, penyebaran pemekaran daerah harus diapresiasi karena memberi tempat bagi aspirasi, pluralitas, otonomi daerah, sesuatu yang diabaikan pada masa Orde Baru. Di sisi lain pada saat yang sama, fenomena pertumbuhan daerah secara besar-besaran menimbulkan masalah baru. Permasalahan yang dapat muncul akibat tergesa-gesa di wilayah yang mengalami pemekaran wilayah antara lain ketidajelasan geografis, kerangka kelembagaan masyarakat yang tidak terdefinisi akan menghambat keberlanjutan sosial di sektor tersebut dan tidak berjalan mulus. Seperti rencana tata ruang wilayah (RTRW) yang demikian lemah dalam pemetaan akan menyulitkan penduduk untuk memanfaatkan kebutuhan administratif untuk menjadi warga negara Indonesia. Kemudian masalah kepemimpinan yang selalu menjadi bagian tersulit dalam pengambilan keputusan pemerintah sehingga menimbulkan masalah baru (Muqoyyidin, 2013).

Menurut hasil evaluasi Departemen Dalam Negeri (2006) dalam Andik Wahyun (2013) terhadap 2 provinsi, 40 kabupaten dan 15 kota, menampilkan 79 persen daerah baru belum mempunyai batas wilayah yang jelas. 19 Dari 104 daerah pemekaran yang disurvei, sekitar 76 daerah bermasalah dan 148 daerah otonom baru juga dihadapkan pada berbagai tantangan, termasuk pendanaan relokasi pegawai, peralatan dan dokumen (P3D), batas wilayah, dukungan keuangan, mutasi PNS dan pengisian peran serta prosedur. Sebanyak 83 persen dari 148 daerah yang muncul dari pemekaran, kondisi keuangan daerahnya tidak memenuhi kriteria pengendalian anggaran. Sementara teorinya untuk mempromosikan layanan publik, dalam praktiknya dana publik telah digunakan untuk dana politik. Merujuk pada temuan BPK tentang Daerah Otonomi Baru, output keuangan daerah yang baru berkembang menjadi sangat penting dan masalah kekurangan SDM sedang diatasi. Hal ini juga diperkuat dengan temuan laporan Direktorat Otonomi Daerah BAPPENAS (2004) yang menyatakan bahwa pelayanan masyarakat di sejumlah DOB belum membaik karena menghadapi berbagai kendala, baik kelembagaan, infrastruktur maupun sumber daya manusia. 
Disisi lain, pemekaran daerah tidak selamanya dapat diraih secara mudah. Ada juga upaya pemekaran daerah tidak mendapat dukungan penuh dari berbagai daerah yang ingin memekarkan diri. Ini dapat dilihat dari rencana pemekaran Provinsi Cirebon yang mendapat penolakan oleh dari Kabupaten Majalengka dan Kabupaten Kuningan yang enggan untuk bergabung menjadi bagian dari Provinsi Cirebon. Penolakan ini yang kemudian membuat pemekaran Provinsi Cirebon sampai saat ini belum dapat terwujud (Ramdhani, 2019).

Oleh karena itu, penelitian ini bertujuan menggambarkan faktor-faktor yang melatarbelakangi rencana pemekaran Kota Meulaboh sebagai Daerah Otonomi Baru dan persepsi masyarakat Aceh Barat terkait rencana pemekaran Kota Meulaboh sebagai Daerah Otonomi Baru.

\section{METODE}

Metode yang dipakai pada penelitiaan ini yaitu penelitian kuantitatif dengan metode survey. Penelitian survey adalah penelitian yang tidak menyampaikan perlakuan apapun kepada responden dan hanya mengumpulkan data dengan menggunakan instrumen yang sudah ditentukan. Dalam penelitian survey fokus penelitian sangat penting untuk membatasi masalah yang akan diteliti. Sehingga peneliti membatasi masalah yang akan diteliti yaitu persepsi masyarakat terhadap rencana pemekaran. Tujuannya agar masalah yang diteliti dapat dibatasi dan informasi yang didapat disesuaikan dengan penelitian serta menghindari banyaknya data tidak penting yang mungkin muncul selama penelitian (Sugiyono, 2009).

Unit analisis dalam penelitian ini adalah responden yaitu orang yang diminta untuk memberikan informasi tentang fakta atau pendapat. Informasi ini dapat disajikan dalam bentuk tertulis, yaitu ketika kuesioner selesai atau saat wawancara telah dijawab. Dengan demikian, responden dalam penelitian ini adalah populasi masyarakat Aceh Barat yang berjumlah 120 orang, yang terdiri dari 10 orang masyarakat dari 12 Kecamatan yang dianggap mengetahui tentang rencana pemekaran Kota Meulaboh. Lokasi penelitian ini berada di Kabupaten Aceh Barat, Provinsi Aceh

Teknik pengambilan data dengan menggunakan kuisioner dan wawancara, studi dokumentasi melalui buku, artikel jurnal dan dokumen pendukung lainnya. Responden yang akan diberikan kuisioner dipilih dengan cara purposive sampling terhadap masyarakat diseluruh Kecamatan di Kabupaten Aceh Barat. Teknik tersebut dipilih agar responden yang diteliti benar-benar memahami dan sesuai sasaran penelitian. Selain itu, metode pengumpulan data dilakukan dengan menggunakan kuesioner berupa daftar pertanyaan untuk mengumpulkan pendapat responden. Kuesioner yang hierarkis bersifat tertutup artinya responden hanya perlu memilih salah satu jawaban yang diberikan dengan model jawaban berjenjang dengan menggunakan skala likert. Dengan demikian, pernyataan yang terdapat dalam skala likert berdasarkan pada teori-teori pendukung dan indikator-indikator yang dianggap mewakili variable penelitian. Klasifikasi jawaban skala likert (1) sangat setuju (ss) skor 5; (2) setuju (s) skor 4; (3) ragu-ragu (r) skor3; (4) tidak setuju (ts) skor 2; dan, (5) sangat tidak setuju (sts) skor 1

Teknik pengolahan data dalam penelitian ini dengan melalui tahap editing dan coding. Setelah memperoleh data-data maka informasi yang diterima akan diolah dengan cara melakukan koreksi kembali (editing) atas data yang telah dikumpulkan dan selanjutnya diklasifikasi (coding) jawaban responden menurut kriteria dan ciri-ciri yang telah ditetapkan. Klasifikasi dikerjakan dengan menandai setiap jawaban dengan tanda kode tertentu (biasanya angka). Dalam melakukan analisis data peneliti melakukan (1) reduksi data yaitu pemilahan, penyederhanaan, dan abstraksi data yang muncul dari kuisioner dan wawancara yang telah dilakukan; (2) penyajian data yaitu penyusunan data secara sistematis untuk menjelaskan masalah yang diteliti; dan, (3) penarikan kesimpulan. Tujuannya agar pengujian terhadap hipotesis dapat dilakukan. Hipotesis pada penelitian ini yaitu terdapat perbedaan persepsi masyarakat Aceh Barat terkait rencana pemekaran Kota Meulaboh sebagai Daerah Otonomi Baru. Persepsi masyarakat dipengaruhi oleh (1) usia; (2) pendidikan; (3) motivasi; (4) pengalaman; (5) lingkungan sosial; (6) akses atas informasi; dan, (7) pengetahuan tentang pemerintahan.

\section{HASIL DAN PEMBAHASAN \\ Karakteristik Responden}

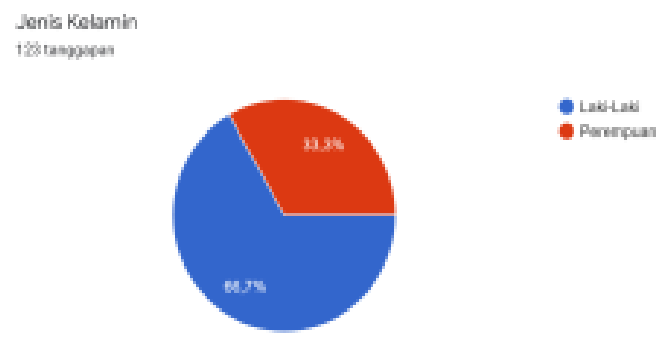

Data grafik di atas menunjukkan bahwa responden berjumlah 123 orang yang terdiri dari unsur masyarakat 12 Kecamatan dilingkup Kabupaten Aceh Barat. Dari 123 responden, 82 orang $(66,7 \%)$ berjenis kelamin laki-laki dan 41 orang $(33,3 \%)$ berjenis kelamin perempuan.

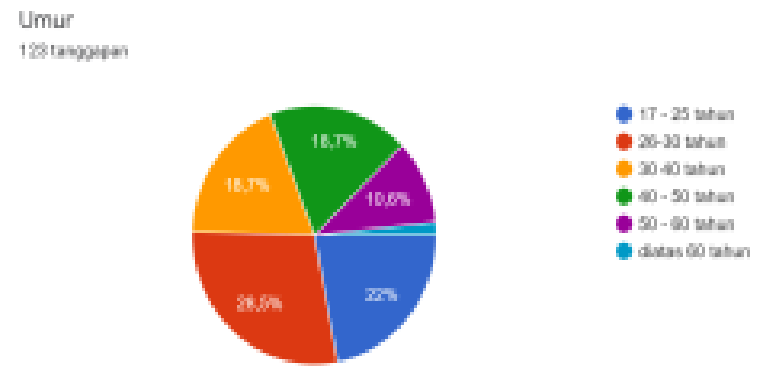

Data grafik di atas menunjukkan bahwa 27 orang (22\%) berusia 17-25 tahun, 35 orang (28,5\%) berusia 26-30 tahun, 23 orang $(18,7 \%)$ berusia $30-40$ tahun, , 23 orang $(18,7 \%)$ berusia 40-50 tahun, 13 orang (10,6\%) berusia 50-60 tahun, dan 2 orang (1,6\%) berusia di atas 60 tahun. 

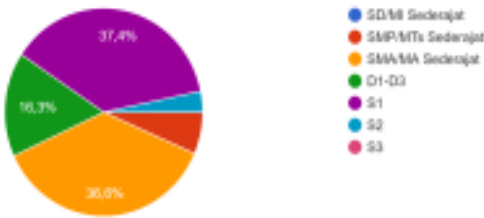

Data grafik di atas menunjukkan 8 orang $(6,5 \%)$ berpendidikan SMP/MTs sederajat, 45 orang (36,6 \%) berpendidikan SMA/MA sederajat, 20 orang (16,3 \%) berpendidikan D1-D3, 46 orang (37,4 \%) berpendidikan S1 dan 4 orang $(3,3 \%)$ berpendidikan S2.
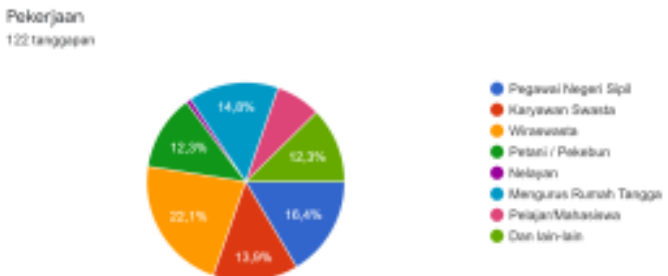

Data grafik di atas menunjukkan bahwa dari 123 responden, 20 orang (16,4\%) bekerja sebagai pegawai negeri sipil, 17 orang $(13,9 \%)$ bekerja sebagai karyawan swasta, 27 orang $(22,1 \%)$ bekerja sebagai wiraswasta, 15 orang $(12,3 \%)$ bekerja sebagai petani, 1 orang $(0,8 \%)$ bekerja sebagai nelayan, 18 orang $(14,8$ $\%)$ bekerja sebagai mengurus rumah tangga, 9 orang $(7,4 \%)$ bekerja sebagai pelajar/mahasiswa dan 15 orang (12,3\%) memiliki pekerjaan selain yang telah dijelaskan di atas.

\section{Faktor-Faktor yang Melatarbelakangi Rencana Pemekaran Kota Meulaboh Sebagai Daerah Otonomi Baru}

Apabah Ands tahu tentang rencana pemelaran Koea Moulaboh? 12 tompen

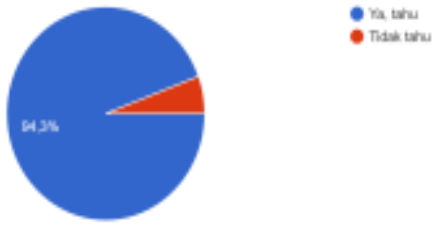

Dari grafik di atas menunjukkan bahwa 116 orang (94,3\%) mengetahui rencana pemekaran Kota Meulaboh dan 7 orang $(5,7 \%)$ tidak mengetahui rencana pemekaran Kota Meulaboh.

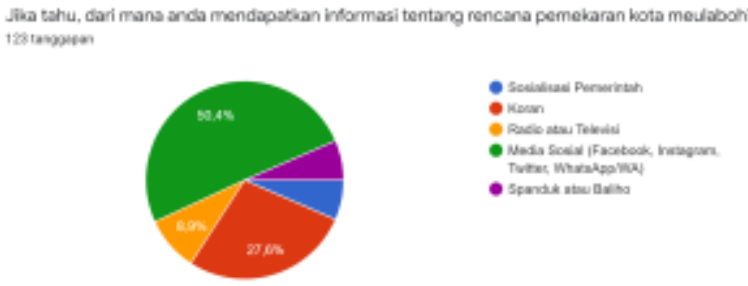

Dari grafik di atas menunjukkan bahwa 8 orang $(6,5 \%)$ tahu dari sosialiasi Pemerintah, 34 orang $(27,6 \%)$ tahu dari koran, 11 orang $(8,9 \%)$ tahu dari radio atau televisi, 62 orang $(50,4 \%)$ tahu dari media sosial (facebook, instagram, twitter, whatsapp / WA) dan 8 orang (6,5\%) tahu dari spanduk atau baliho.

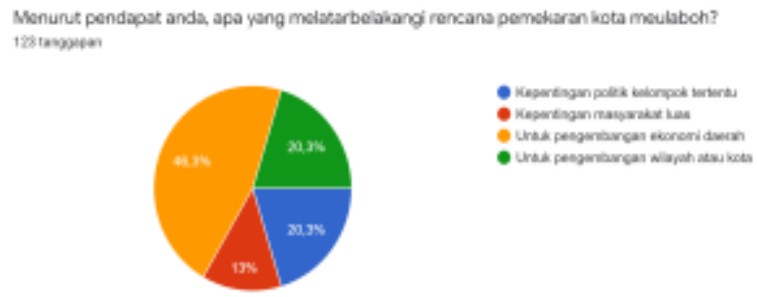

Dari grafik di atas menunjukkan bahwa 25 orang (20,3\%) rencana pemakaran Kota Meulaboh dilatarbelakangi kepentingan politik kelompok tertentu, 16 orang (13\%) dilatarbelakangi kepentingan masyarakat luas, 57 orang (46,3 $\%$ ) dilatarbelakangi untuk pengembangan ekonomi daerah, 25 orang $(20,3 \%)$ dilatarbelakangi untuk pengembangan wilayah atau kota. Data di atas juga menunjukkan bahwa mayoritas masyarakat menyatakan bahwa rencana pemekaran Kota Meulaboh dilatarbelakangi untuk pengembangan ekonomi daerah dan pengembangan wilayah atau Kota. Selain dua hal tersebut, rencana pemekaran Kota Meulaboh juga dilatarbelakangi oleh faktor untuk mendekatkan pelayanan kepada masyarakat. Pada grafik dibawah ini menunjukkan bahwa 96 orang (78 \%) masyarakat Aceh Barat menyatakan bahwa rencana pemekaran Kota Meulaboh bertujuan untuk mendekatkan pelayanan kepada masyarakat.

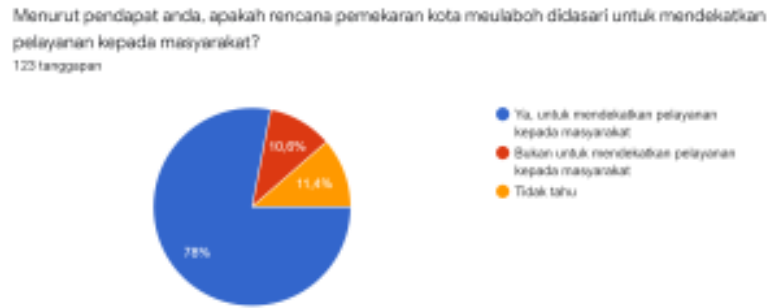

Selain itu, dari data grafik yang lain menunjukkan bahwa rencana pemekaran Kota Meulaboh juga dilandasi agar mendapatkan anggaran pembangunan yang lebih banyak dari Pemerintah Pusat. Sebagaimana data grafik dibawah ini bahwa 102 orang $(82,9 \%)$ menyatakan rencana pemekaran Kota Meulaboh juga dilandasi agar mendapatkan anggaran pembangunan yang lebih banyak dari Pemerintah Pusat.

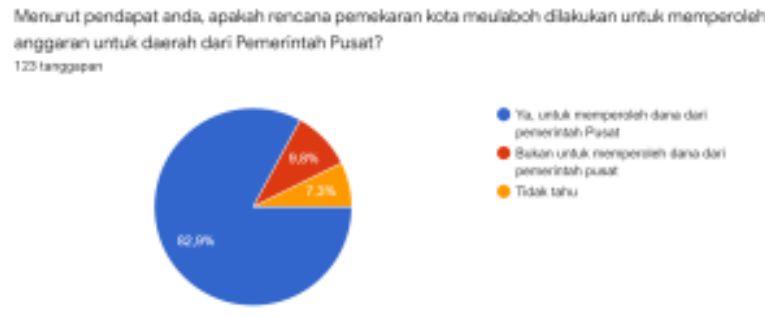

Akan tetapi, rencana pemekaran Kota Meulaboh tidak dilatarbelakangi oleh faktor ketidakadilan dalam pembangunan dan pengisian jabatan politik di Kabupaten Aceh Barat. Ini terlihat dari gambaran grafik di bawah ini. Dari 123 responden, 71 orang $(57,7 \%)$ menyatakan bahwa rencana pemekaran Kota Meulaboh bukan karena ketidakadilan dalam pembangunan dan pengisian jabatan politik di Kabupaten Aceh Barat 


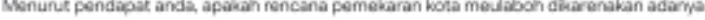

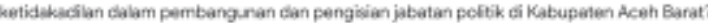
Irstangousen
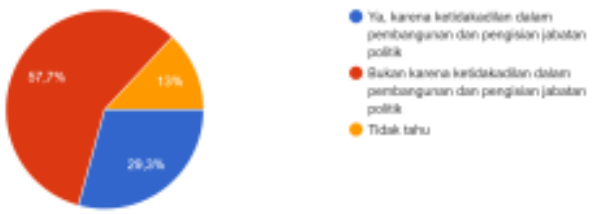

\section{Persepsi Masyarakat Aceh Barat Terkait Rencana Pemekaran Kota Meulaboh Sebagai Daerah Otonomi Baru}

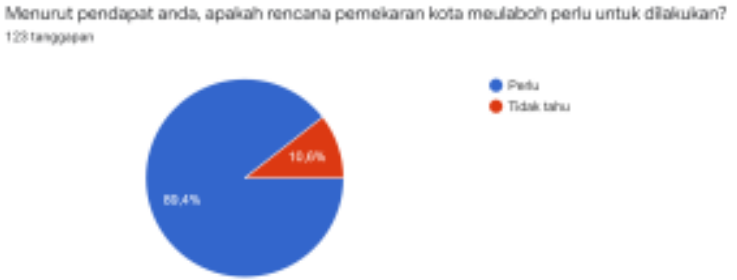

Dari grafik diatas menunjukkan bahwa 110 orang $(89,4 \%)$ menyatakan rencana pemekaran Kota Meulaboh perlu untuk dilakukan dan 13 orang $(10,6 \%)$ menyatakan rencana pemekaran Kota Meulaboh tidak perlu dilakukan.

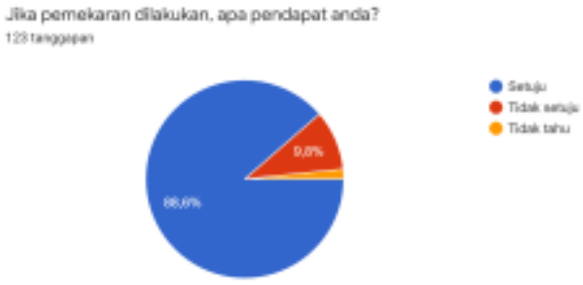

Dari grafik di atas menunjukkan bahwa 109 orang (88,6\%) setuju dilakukan pemekaran Kota Meulaboh, 12 orang (9,8 \%) tidak setuju dilakukan pemekaran Kota Meulaboh dan 2 orang (1,6\%) menjawab tidak tahu.

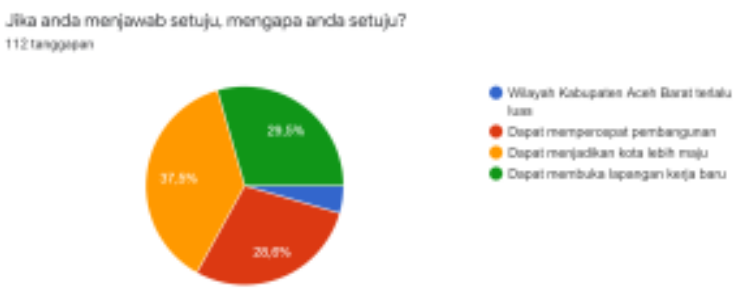

Pada grafik di atas menunjukkan bahwa ada beberapa alasan yang mempengaruhi masyarakat setuju dilakukan pemekaran Kota Meulaboh. 42 orang (37,5 \%) menyatakan pemekaran Kota Meulaboh dapat menjadikan kota lebih maju, 33 orang $(29,5 \%)$ menyatakan pemekaran Kota Meulaboh dapat membuka lapangan kerja baru, 32 orang (28,6 \%) menyatakan pemekaran Kota Meulaboh dapat mempercepat pembangunan dan 5 orang $(4,5 \%)$ menyatakan pemekaran Kota Meulaboh dikarenakan wilayah Kabupaten Aceh Barat sangat luas.
Hal yang sama juga dapat dilihat dari masyarakat yang tidak setuju dilakukan pemekaran Kota Meulaboh. Sikap atau pendapat kelompok ini juga dipengaruhi oleh bebeagai alasan. Dari data grafik dibawah ini menunjukkan bahwa 21 orang (36,8 \%) menyatakan bahwa pemekaran Kota Meulaboh bukan sesuatu hal yang mendesak, 17 orang $(29,8 \%)$ menyatakan bahwa pemekaran Kota Meulaboh hanya kepentingan kelompok tertentu, 13 orang $(22,8 \%)$ menyatakan bahwa pemekaran Kota Meulaboh hanya buang-buang uang rakyat dan 6 orag (10,5\%) menyatakan sudah nyaman dengan kondisi sekarang sehingga tidak perlu dilakukan pemekaran.
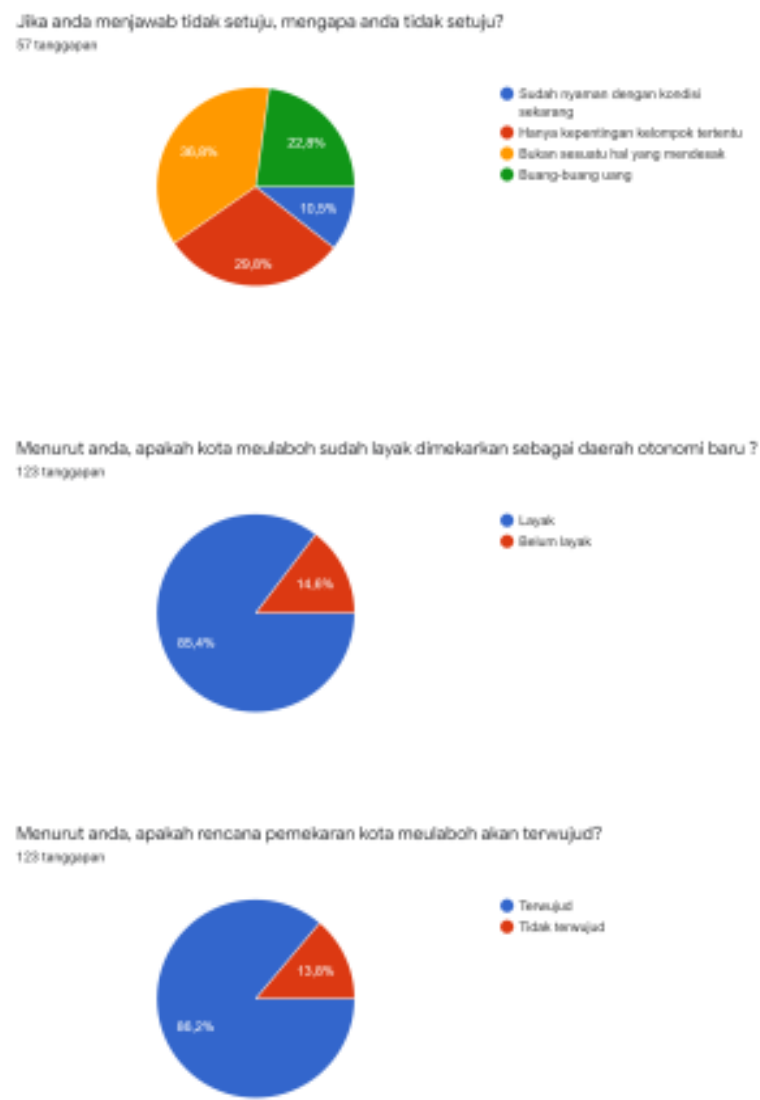

Dari berbagai persepsi masyarakat Aceh Barat, 105-106 orang (85-86 \%) menyatakan bahwa Kota Meulaboh sudah layak dimekarkan sebagai daerah otonomi baru dan pemekaran Kota Meulaboh akan terwujud setelah mendapat persetujuan dari Pemerintah Pusat. Sedangkan 16-17 orang (13-14 \%) lainnya menyatakan bahwa Kota Meulaboh belum layak dimekarkan sebagai daerah otonomi baru dan tidak akan terwujud.

\section{KESIMPULAN}

Berdasarkan hasil penelitian dapat disimpulkan mayoritas Masyarakat Aceh Barat menyatakan bahwa rencana pemekaran Kota Meulaboh dilatarbelakangi oleh faktor untuk pengembangan ekonomi daerah dan pengembangan wilayah atau Kota. Selain itu, rencana pemekaran Kota Meulaboh juga bertujuan untuk mendekatkan pelayanan kepada masyarakat dan untuk mendapatkan anggaran pembangunan yang lebih banyak dari Pemerintah Pusat. Akan tetapi, rencana pemekaran Kota Meulaboh tidak dilatarbelakangi oleh faktor ketidakadilan dalam pembangunan dan pengisian jabatan politik di Kabupaten Aceh Barat. 
Disamping itu, mayoritas Masyarakat Aceh Barat setuju dilakukan pemekaran Kota Meulaboh. Sikap ini dipengaruhi oleh berbagai alasan diantaranya pemekaran Kota Meulaboh dapat menjadikan kota lebih maju, pemekaran Kota Meulaboh dapat membuka lapangan kerja baru, pemekaran Kota Meulaboh dapat mempercepat pembangunan dan karena wilayah Kabupaten Aceh Barat sangat luas. Selain itu, mayoritas Masyarakat Aceh Barat juga menyatakan bahwa Kota Meulaboh sudah layak dimekarkan sebagai daerah otonomi baru dan pemekaran Kota Meulaboh akan terwujud setelah mendapat persetujuan dari Pemerintah Pusat

\section{REFERENSI}

Alcock. (1997). Understanding Poverty (Second). Palgrave.

Bauw, A. (2018). Prosedur pemekaran daerah berdasarkan Undang-undang nomor 23 tahun 2014 Tentang pemerintahan daerah. LEGAL PLURALISM, 8(1), 1-14.

Beli, W. S. (2016). Hidden Power Dalam Politik Pemekaran Di Nusa Tenggara Timur. Journal of Government: Kajian Manajemen Pemerintahan Dan Otonomi Daerah, 2(1), 1-17.

Huda, N. (2014). Desentralisasi Asimetris Dalam NKRI, Kajian Terhadap Daerah Istimewa, Daerah Khusus, dan Otsus. Nusa Media.

Ikhsan, I. (2015). RELASI OTONOMI KHUSUS DAN PENGURANGAN KEMISKINAN DI PROVINSI ACEH. Jurnal Public Policy. https://doi.org/10.35308/jpp.v0i0.698

Ikhsan, I. (2016). Pemekaran Daerah: Peluang dan Tantangan Bagi Pemekaran Kota Meulaboh. Jurnal Public Policy, 2(2), 159-166. https://doi.org/10.35308/jpp.v2i2.764

Ikhsan, Suwaryo, U., Yani Yuningsih, N., \& Van Ylst, F. (2020). SPECIAL AUTONOMY FUND TO REDUCE POVERTY: DOES IT WORK? Humanities \& Social Sciences Reviews, 8(3), 362-370. https://doi.org/10.18510/hssr.2020.8339

Kombuno, H. (2017). Pemekaran Daerah Berdasarkan UndangUndang Nomor 23 Tahun 2014 Tentang Pemerintahan Daerah. Legal Opinion, 5(2), 1-15.

Makagansa, H. R. (2008). Tantangan Pemekaran Daerah (FusPad).

Muqoyyidin, A. W. (2013). Pemekaran Wilayah dan Otonomi Daerah Pasca Reformasi di Indonesia: Konsep, Fakta Empiris dan Rekomendasi ke Depan. Jurnal Konstitusi, 10(2). https://doi.org/10.31078/jk\%25x

Murniati, M. (2017). Analisis Dampak Pemekaran Wilayah Terhadap Pendapatan Perkapita Dikabupaten Kerinci. JMAS (Jurnal Manajemen Dan Sains), 2(1), 121. https://doi.org/10.33087/jmas.v2il.20

Ramdhani, H. (2019). Realitas Elit Politik Lokal dan Persepsi Masyarakat dalam Proses Pemekaran Daerah. JPPUMA Jurnal Ilmu Pemerintahan Dan Sosial Politik Universitas Medan Area, 7(2), 219. https://doi.org/10.31289/jppuma.v7i2.3014

Reiza Macella, A. D. (2020). Kinerja Organisasi Publik dalam Mendukung Penyelenggaraan Pelayanan di Kantor Kecamatan Johan Pahlawan. Jurnal Public Policy, 6(1), 51. https://doi.org/10.35308/jpp.v6il.1672

Sugiyono. (2009). Metode Penelitian Kuantitatif, Kualitatif dan ReDD. Alfabeta.

Trikurniasih, E., Handayani, R., Santoso, A., \& Soleh, A. (2019). Analisis Dampak Pemekaran Daerah Terhadap Kinerja Keuangan dan Pelayanan Publik. Ekonomis: Journal of $\begin{array}{lll}\text { Economics and } & \text { Business, }\end{array}$ https://doi.org/10.33087/ekonomis.v3i2.76

Yani, T. A. (2016). Pengadministrasian Penyertaan Modal Daerah Kepada Perusahaan Daerah Air Minum Sebagai Tanggung Jawab dalam Mensejahtarakan Rakyat. Jurnal Public Policy, 2(2). https://doi.org/10.35308/jpp.v2i2.761 